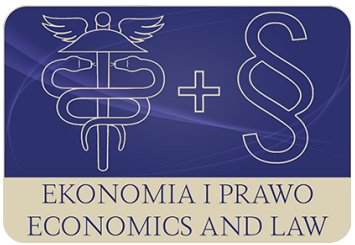

EKONOMIA I PRAWO. ECONOMICS AND LAW

Volume 18, Issue 3, September 2019

p-ISSN 1898-2255, e-ISSN 2392-1625

www.economicsandlaw.pl

EKONOMIA I PRAWO

ORIGINAL ARTICLE

received 30.10.2018; revised 01.08.2019; accepted 30.09.2019

Citation: Bochenek, M.(2019). Włodzimierz Hagemejer and his work. Ekonomia i Prawo. Economics and Law, 18(3): 251-267. doi:10.12775/EiP.2019.018.

\title{
Włodzimierz Hagemejer and his work
}

\section{MIROSEAW BOCHENEK}

\author{
Nicolaus Copernicus University in Torun, Faculty of Economic Sciences and Managenent, \\ Department of Economics, ul. Gagarina 13A, 87-100 Torun, Poland \\ ఐ bochenek@umk.pl \\ (iD) orcid.org/0000-0002-5914-2789
}

\begin{abstract}
Motivation: W. Hagemejer was an assistant lecturer at the Jagiellonian University in Krakow and a professor at Nicolaus Copernicus University in Torun. He also worked in five scientific institutes. He fought during the Second World War on the African and Italian fronts. During the Stalinist period, he was unjustly detained in prison. Nevertheless, he was forgotten by economists.

Aim: The aim of the article is to extract from oblivion the life and scientific achievements of W. Hagemejer. The research subject of the following considerations is an attempt at an evaluation of the originality of his works.

Results: W. Hagemejer published valuable works on the elasticity of demand, the condition of the Polish economy, the structure and development trends of consumption of urban and rural households in connection with market equilibrium, inflation undermining the purchasing power of money and people's savings, the profitability of agricultural production, economic history, and many other issues. Most of his publications are of a math-

ematized character and contain a wealth of statistical material. He was a supporter of quantitative methods in economics.
\end{abstract}

Keywords: history of economic thought; elasticity of demand; market equilibrium; consumption; purchasing power of money; mathematical economy

JEL: B20; B23; D12; D31; D50; E21

\section{Introduction}

In 2018, the Faculty of Economic Sciences and Management at Nicolaus Copernicus University in Torun celebrated its 50th anniversary. On that occasion, the creators and employees of the faculty, the history of cathedrals and other 
events were remembered. The department's oldest chair is the Chair of Economics, and its first professor was W. Hagemejer - a completely forgotten figure in Polish economics. The aim of this article is to familiarize the economists with his way of life and achievements in the field of the science pursued by him. The author of this study used the analysis of available professional literature as a research method.

\section{Biography of W. Hagemejer ${ }^{1}$}

W. Hagemejer was born in Krakow on May 4, 1908. After receiving a secondary school certificate in 1929 from the M. Rej State Gimnazjum in Kielce, he undertook studies at the Faculty of Law of the Jagiellonian University in Krakow, from which he graduated obtaining a master's degree in law in 1932. In 1933-1934 he worked as a clerk in the Tax Chamber in Krakow, then in the Postal Savings Bank in Warsaw, and finally, in the Institute of Social Affairs in Warsaw.

On October 1, 1934, he assumed the post of assistant lecturer in the Institute of Economics of the Polish Academy of Arts and Sciences in Krakow directed by prof. Adam Heydel. Concurrently, he co-edited with A. Heydel a new journal Studia Ekonomiczne. Economic Studies. In 1935, W. Hagemejer submitted his doctoral dissertation at the Faculty of Law of the Jagiellonian University entitled Empirical research on the elasticity of demand with the application for alcohol sale in 1928-1933. On this basis, he obtained a doctoral degree in law on May 31, 1935. Two years later, on September 1, 1937, he became a senior assistant at the Economic Seminar of the Faculty of Law of the Jagiellonian University, headed by A. Krzyżanowski. Thanks to a scholarship from the Rockefeller Foundation, in 1937-1938, he studied at the London School of Economics, the University of Cambridge, Lunds Universitet, and Handelshöhskolan in Stockholm.

After the outbreak of World War II, he went to Hungary and then managed to get to Palestine, where he volunteered for the Independent Carpathian Rifle Brigade. He was awarded the Cross of Valour for participation in the battle for Tobruk. After the transformation of the Brigade into the 3rd Carpathian Rifle Division and its inclusion in the II Corps of the Polish Army in the East he participated in the operation on the Apennine Peninsula. From Italy, he managed to get to Great Britain and was involved in the Economic Planning Commission of the Ministry of Industry by the Polish Government in Exile in London. He returned to Poland in 1946 and was employed as director of the General Economic Research Department at the Institute of National Economy at the Praesidium of the Council of Ministers.

On November 1, 1946, he was appointed deputy professor and director of the Department of Political Economy at the Faculty of Law and Economics

1 The following sources and materials were used to develop the biography of W. Hagemejer: Kowalik (2006, p. 10, 93-95), Hegemejer (n.d.), Żukowski (2017, p. 458), Polskie Towarzystwo Ekonomiczne (2005, p. 5). I have obtained valuable information from his son - Krzysztof Hagemejer, PhD for which I thank him warmly. 
of Nicolaus Copernicus University in Torun. His employment at NCU expired on June 30, 1949. In 1949, the National Economy Institute was incorporated into the Central Statistical Office. In the new structure, W. Hagemejer was appointed director of the Trade and Price Department. During this period he met Helena Dyoniza Tatar-Zagórska, whom he married on June 6, 1950. To this marriage, in 1951, son Krzysztof Wacław Antoni was born².

On February 1, 1952, W. Hagemejer was arrested unjustly and imprisoned in the detention centre at ul. Rakowiecka. After being released from prison in June 1954, he was employed as an office worker in the finance and accounting department of the Central Office of Publishing Houses of the Graphic Industry and Book Industry Association. In the years 1954-1956 he was a scientific secretary of the Main Board of the Polish Economic Society. In 1957, W. Hagemejer appointed to the post of deputy professor at the Department of Economic Sciences of the Polish Academy of Sciences.

In the academic year 1958/1959 W. Hagemejer was re-employed as a professor and head of the Department of Political Economy at the Faculty of Law of Nicolaus Copernicus University in Torun. In 1960, he received a six-month scholarship from the Ford Foundation to deepen his knowledge of econometric methods at Harvard University. Unfortunately, in 1961 the Ministry of Higher Education did not consent to his continueing employment as a professor, but only as a senior lecturer. The Ministry's decision was rejected by W. Hagemejer, resulting in the termination of his service relationship with Nicolaus Copernicus University in Torun on October 1, 1961. The following year he received a 12-month contract in the Department of Economic Research and Analyses of the International Labour Office in Geneva. At the beginning of the 1970s, the Department of Economic Sciences of the Polish Academy of Sciences was liquidated. H. Hagemejer was appointed to the position of associate professor at the Planning Institute at the Council of Ministers, which he held until his retirement in 1978. He died in Warsaw on May 9, 1994.

Working in two Polish universities (Jagiellonian University and Nicolaus Copernicus University), in four national scientific institutes (IE PAU, IGN, ZNE PAN and IP at RM) and one foreign (MBP) he thoroughly mastered basic knowledge in economics, but in his research he focused on several issues.

\section{An analysis of the economic situation}

W. Hagemejer (1947a, pp. 31-32; 1947b, pp. 1-3) presented the economic situation of Poland during its reconstruction after World War II and in the second half of the 1950s in several reports. In the first study he noted that in 1946, the national economy started to grow visibly. Investment goods increased the most, i.e. by $47 \%$ on an annual basis, and the production of consumer goods by 38\%. Unfortunately, the level of industrial production from 1938 had not yet been achieved. The employment rate in industry was favourable, increasing

\footnotetext{
${ }^{2}$ W. Hagemejer's grandson, Jan Włodzimierz Hagemejer, is also an economist.
} 
by $36.7 \%$, but the productivity of work did not improve. Unemployment continued to persist, mainly among women and unskilled people. The state budget recorded a deficit. Investments were mainly directed at the reconstruction of industry, transportation, cities and towns, and housing estates. Free market prices increased by $31 \%$. The imbalance on the consumer goods market was eased by the UNRRA supplies worth PLN 807 million. In his next study, he noted that in the first half of 1947, production increased by $33 \%$ compared to the first half of the previous year, with the highest increase in the production of investment goods $(40 \%)$ and consumer goods $(34 \%)$. The increase in production was accompanied by an increase in employment in the state-owned industry by $18 \%$. The state budget recorded a surplus, which was directed to finance planned investments and the repayment of debts at the National Bank of Poland (Hagemejer, 1947c, pp. 1-2). In the subsequent report, he highlighted the country's economic situation in the second half of 1947. A very high growth rate of industrial production was maintained, both in the second half of the year - by $16.8 \%$ and in the whole of 1947, i.e. by 32\% compared to 1946 As in previous years, the production of investment goods grew the fastest. Employment in industry increased by $7 \%$, and there was also an increase in labour productivity, and an increase in wages. With the use of public funds, investments were maintained at a level higher than in previous periods. The stability of free market prices was noticed not only in the second half of 1947, but also in the first months of 1948 (Hagemejer, 1948b, pp. 1-2).

Ten years later, W. Hagemejer stated that since 1953 there had been significant changes in the structure of the division of the national income. The most visible was the increase in real wages, which caused an increase in consumption. Unfortunately, disproportions in the development of individual industries deepened. This phenomenon was the result of the implementation of large investment projects in the defence industry, at the expense of neglect of mining, energy, and construction industries. The underdevelopment of these branches led to restrictions on the supply of energy and building materials for industry and households. A positive phenomenon from 1956 and early 1957 was an increase in farmers' wages and income. The surplus of demand at that time was liquidated mainly by the foreign trade deficit. Unfortunately, domestic industry did not keep up with the growing demand for high-end consumer goods (Hagemejer, 1957, pp. 1-6). In his next publication he pointed out that in 1958 the national economy was to achieve two goals. The first goal was to maintain a high rate of economic growth, the second a noticeable increase in farmers' wages and income. However, the prerequisite for ensuring development processes was to maintain the market equilibrium. The problem of market equilibrium was to be solved by a significant increase in the production of consumer goods at the expense of reducing the production of production means. Unfortunately, there was no proper shift in production, and both sectors continued to develop at a similar pace. Nevertheless, in 1957 market equilibrium was achieved, which was the result of an increase in industrial production and the growth of labour 
productivity, an increase in foreign trade deficit, an increase in population savings, employment reduction in the non-productive sphere, and a significant increase in the level of prices (6\% compared to the previous year). According to W. Hagemejer (1958, pp. 1-5), most of these factors affected the equilibrium in the short-term. An increase in productivity and in the mass of goods proved insufficient. The greatest weakness of the Polish economy was the continuing underdevelopment of the industry producing means of consumption. The foreign trade deficit was financed with loans from the USSR and the USA. An important factor maintaining the equilibrium was the increased supply of agricultural commodities, which made it possible to increase the production of the agro-food industry.

\section{Elasticity of demand}

W. Hagemejer raised the problems related to the research into demand in the article titled Elastyczność popytu na przewóz towarów (The elasticity of demand for transport services). He noted that in this type of empirical research, transport costs are generally omitted, although they play an important role in cases of larger distances between outlets and the location of manufacturing plants. Transport services are included in the factors of production that are consumed in the manufacturing process of finished goods. Changes in freight rates are reflected in the transport volumes. Therefore, it is considered that transport cannot be replaced by a different factor of production, i.e. there is no substitute for transport services. However, it is possible to refrain from using transport through changes in the spatial distribution of manufacturing facilities. If the transport rates are too high, the entrepreneurs can move the production plants closer to the outlets. W. Hagemejer (1935a, pp. 31-35) pointed out that the elasticity of demand for specific transport services (road or water transport) relative to the price is primarily determined by the possibility of replacing some means of transport by others. According to the author of the cited article: 'the elasticity of demand for transport services is therefore the sum of two components, i.e. the flexibility of substitution of a given means of transport by others, and the elasticity of demand resulting from the possibility of changing the price of goods, their production, and consumption in the event of a change in the prices of transport services' (Hagemejer, 1935a, p. 37). Empirical data indicate that as technological progress increases, the volume and scope of the use of transport services expands, and, at the same time, the possibilities of replacing one type of transport by a different type are increasing. However, a reduction in the price of transport services leads to an even greater increase in transport, because reducing freight rates leads to an increase in the supply and use of transport services. It follows that the change in tariffs, or the price of transport, triggers the demand response not directly, but through changes in all prices and through the amount of goods produced and consumed. W. Hagemejer (1935a, pp. 37-41) concluded that the volume of transport depends not only on the price of transport, but 
also on the distance of transport. The greater the distance between the market and the place of production, the higher the price of the product. Transport costs are, therefore, the basic factor differentiating prices in different markets. The elasticity of demand for transport services is diverse "because (1) the elasticity of demand for transport results not only from the elasticity of demand for finished products, but also from the elasticity of their supply, and (2) the elasticity of demand for transport services depends on the ratio of the price of the finished good to the price of transport falling on it' (Hagemejer, 1935a, p. 43).

\section{Market equilibrium}

W. Hagemejer was interested in both the empirical and theoretical aspects of market equilibrium. In the work titled Równowaga i nierównowaga rynkowa w Polsce w roku 1957 (Market equilibria and disequilibrium in Poland in 1957), co-written with Zdzisław Fiejka, Wacław Przelaskowski, Krzysztof Rey, Eugeniusz Rychlewski, and Zbigniew Szulz, its authors pointed out that the market disequilibrium which had arisen in 1957 was the result of wage increases introduced in 1956-1957, as well as the increase in purchase prices of agricultural products, which increased the purchasing power of the population. The shift of production could not keep up with these moves regarding the division of national income. In the analysed year, the increase in income of the population was not accompanied by a corresponding increase in the production of consumer goods. Although in 1957 there was a significant, i.e. 6\% increase in labour productivity, it was not sufficient to ensure equilibrium. To improve the supply of the domestic market, exports were also reduced, at the expense of a deficit in foreign trade. The factor that led to the restoration of equilibrium was the increase in prices of all goods and services purchased by the population, which, in 1957, amounted to $6.9 \%$ compared to the previous year. The striving for equilibrium resulted from the awareness that it determines the continuation of the development processes of the entire economy (Fiejka et al, 1959, pp. 105-110).

In the article Równowaga rynkowa, równowaga agregatowa, równowaga bilansowa (Market equilibrium, aggregate equilibrium, incomes-expenditures equilibrium), W. Hagemejer (1963a, pp. 5-10) stated that the creators of theoretical models usually understand equilibrium as a static situation, meaning the absence of any internal forces, as well as constancy in the elements of the model. The equilibrium understood in this way is a static equilibrium. On the other hand, dynamic equilibrium takes place when growth processes disturb the existing equilibrium, after which a new equilibrium develops, i.e. the equilibrium is shifted from one position to another. The factor of time is connected with equilibrium, i.e. with its duration. As equilibrium one can also understand such a state when some quantitative proportions persist, both in the sphere of production and in the sphere of consumption. States of non-equilibrium occur in situations of tension that may result from the predominance of demand or supply. It is also possible that there is a general equilibrium, i.e. the monetary income of the pop- 
ulation is equal to the supply of goods, and at the same time, some markets are unbalanced. This situation indicates that in the existing price system, the supply and demand structures are incompatible.

In the work Rezerwy pieniężne ludności, dochody i równowaga (Cash holdings of the population, incomes and equilibrium), W. Hagemejer and W. Przelaskowski (1965a, pp. 36-39) indicate that the creation of cash reserves by the population is a potential threat to the emergence of an inflationary tendency in the form of a latent inflation. In the years 1955-1963 a significantly larger increase in population's cash reserves and bank deposits was observed compared to the sales of goods and services. Rising cash reserves of the population are not yet a negative phenomenon. They become a threat to the general market equilibrium when these funds are released and lead to the surplus of demand over supply.

In the articles Handel wewnętrzny i spożycie w latach 1960-1964 (Domestic trade and comsumption in the years 1960-1964) and Vètrešna targovija i potreblenieto $v$ Polše prez perioda 1960-1964, W. Hagemejer and W. Przelaskowski (1966a, pp. 73-88; 1967, pp. 96-107), held the position that in the analysed period national income increased by $5.6 \%$ per year, whereas real wages by $4 \%$. It seemed that the above economic indicators would ensure the equilibrium of demand and supply. Meanwhile, the unbalanced market in previous periods, the low and uneven growth rate of agricultural production and the food industry, as well as the deficit in foreign trade were the reasons why the internal market could not be balanced in the analysed period. According to the authors of the article, the increase in the wage bill was not offset by the increase in the production of consumer goods and the supply of these goods was not adjusted to the needs of the population. This situation created a threat of equilibrium disruption. Paradoxically, consumption increased less than the national income, and wages grew slower than labour productivity. In connection with the threat to market equilibrium, caused by the increase in the population's income and consumption, prices of many consumer goods were raised. In the years 1960-1964 prices of goods and services in general increased (with 1961=100) by 6\%. Unfortunately, the new price level and structure did not provide partial balances in all markets.

\section{Consumption}

W. Hagemejer (1938a, pp. 364-365) began his considerations of consumption by explaining this category. Under the entry word Konsumpcja (Comsumption) he pointed out that this term means both the spending of part of the disposable income on goods and services by households, and the satisfying of needs through the consumption of economic goods. If individuals behave rationally, they appropriate only pure income for consumption, while they leave their earning assets intact. Consumption expenses change along with the economic situation. In the upward phase of the business cycle, expenses increase, while in the pe- 
riod of decline - they decrease, but the waves of consumption are lower than the waves of national income.

In the study entitled Handel wewnętrzny i spożycie w latach 1955-1960 (Retail sales and comsumption in the years 1955-1960), W. Hagemejer together with W. Przelaskowski (1963, p. 11) stressed that 1956 was characterized by a decrease in the share of accumulation in national income and an increase in the personal wage bill of $15.5 \%$, compared to 1955, while in 1957 an increase of $18.3 \%$, in relation to 1956. As a result, consumption increased more than the national income. The authors of the article noticed that 'in 1956 and 1957 there was a tendency of a relative reduction in the purchase of food and an increase in purchases of industrial goods' (Hagemejer \& Przelaskowski, 1963, p. 29). In their opinion, the most important regularity observed in the analysed period was the increase in commodity consumption, caused by the increase in the monetary income of the population (Hagemejer \& Przelaskowski, 1963, pp. 36-39).

In the article Tendencje rozwojowe spożycia $w$ okresie lat 1949-1963 (Trends of development of personal comsumption in Poland in the period 1949-1963), W. Hagemejer and W. Przelaskowski (1965b, pp. 78-92) noted that the national income in the years 1949-1963 increased more than 2.5 times, while consumption of material goods by only $80 \%$. In addition, the years 1949-1953 were characterized by a high price increase. The consumer price index in 1953 was 195, compared to 1949. Summarizing the period under examination, these authors stated: 'the total growth of consumer spending is small (...). Thus, the tendency observed in other countries to maintain the once archived standard of consumption, at least at the cost of getting rid of savings or debt, is lacking (...). The share of expenditure on durable goods, though constantly growing, is, however, absolutely low' (Hagemejer \& Przelaskowski, 1965b, p. 93).

In the work entitled Metodologia międzynarodowych porównań dochodów ludności (Methodology of international comparisons between theincomes of the population) W. Hagemejer and W. Przelaskowski presented a unique method of determining the rate of consumption and satisfaction of the needs of the population in the socialist countries. The authors of the paper took into account the level of prices in individual countries, the wealth of families based on their household budgets, the balance sheets of people's income and expenditure, and natural consumption, as well as the basket of goods. This led W. Hagemejer and W. Przelaskowski (1966b, pp. 13-23) to create a standardized model budget which can be calculated for each country in a given period. In addition, the authors assumed that the relationships between the volumes of the basket and the real income of the population were linear in nature. Consumption is also a linear function of the real income of the population in the countries studied.

\section{The purchasing power of money}

In the article Sita nabywcza ztotego polskiego w stosunku do rubla $i$ funta szterlinga: próba szacunku (The purchasing power of the Polish Zloty as compared with 
the rouble and the pound sterling: an estimate) W. Hagemejer together with W. Przelaskowski (1958, pp. 89-102) compared the purchasing power of the three currencies in 1955 and 1956, and then decided that the average monthly wage in the United Kingdom is almost twice as high (around 40 pounds sterling) as the wage in Poland (approx. 21 pounds), which meant that in 1956 the average British working family spent twice as much as the average Polish family on consumer goods.

Their book entitled Problemy sity nabywczej pieniadza (Problems of the purchasing power of money) was the culmination of the research of W. Hagemejer and W. Przelaskowski (1968, p. 7 et seq.) on financial issues. Its aim was to discover a regularity in the creation of people's savings deposits and cash resources. No less important were the relationships between the people's monetary funds and changes in the structure of the effective demand. Using the rich empirical material, the authors showed that market equilibrium, which is the occurrence of either a lack of supply of goods and services or a surplus of supply over income, is a frequent occurrence. The authors were the few to prove in the 1960s XX w. the existence of the inflation and deflation phenomena in the planned economy. And so in 1945-1946 the state undertook deflation measures, which caused money hunger, compounded by a rapid increase in industrial production and commodification of agriculture, while in 1947-1949 there was quite high inflation, which was the effect of the reconstruction of damaged economic facilities. In addition, a downward movement in prices occurred in 1954-1956, while a strong rise in prices occurred in 1952. In the years 1950-1955 the state of savings and cash resources of the population was relatively low. A stronger increase in savings occurred in 1951, while in 1953 there was a downward trend related to the increase in prices from 1951 to 1953. In the period of the six-year plan, the population savings were insignificant. This period was also characterized by a low level of consumption, and even a halt in the growth of the standard of living. Admittedly, in the audited period, society strengthened the habit of saving, but, unfortunately, this effort was defeated by inflation. Society lost most, from 6 to $42 \%$ of the real value of savings, by deferring temporarily demand and giving up shopping.

\section{Problems of the agricultural economy}

W. Hagemejer's considerations in the field of the agricultural economy were related to the profitability of production. In a study bearing the title of Land reform and decapitalisation, W. Hagemejer, together with Ludwik Górski and Stefan Schmidt, referred to the issue of the impact of land reform on the profitability of large and small farms and the creation of conditions for the increase of capital. In his part of the study, W. Hagemejer pointed to the benefits of the division of large agricultural holdings, among other things: reduction of income disproportions in society and increase in the aspiration to save by small farmers 
in comparison with owners of large farms. These phenomena may lead to increased capitalization (Górski et al., 1937, pp. 22-24).

In turn in 1963, W. Hagemejer referred to the article by Stefan Felbura titled Ogólna optacalność produkcji rolnej (Profitability of agricultural production). According to W. Hagemejer (1963b, p. 162), the author of the polemical article formulated the thesis that agricultural prices in a limited way affect the profitability of agricultural production. 'The profitability level', wrote W. Hagemejer (1963b, p. 162), 'converted to the unit of production is determined by agricultural prices and unit costs, and the thesis of the article discussed here aims to prove the interconnection of prices and individual cost items, and the profitability is analysed by the author assuming the permanent structure of the global production of small farmers, and the aim of the study is not to find internal shifts in the production structure, but to determine the impact of the general level of agricultural prices on the profitability of such a permanent aggregate of production'. In addition, the author of the quoted article considered that the method of analysis of inter-branch flows should be used to identify the relationship between costs and prices. The solution of the appropriate system of equations gave a result which indicated that with the increase in agricultural prices by 100 , the total costs of agricultural production increase by about 58 . When solving the system of equations, feedbacks appeared, i.e. prices and costs of non-agricultural production depended on agricultural prices, as also the costs of agricultural production depended on the price change in the non-agricultural sector. The above analysis of the dependence system led the author to the conclusion that the increase in agricultural prices leads to an increase in the profitability of agriculture (Hagemejer, 1963b, pp. 163-164).

\section{An analysis of previous economic views}

In the initial period of his scientific activity, W. Hagemejer published three works on the history of economic thought. In the article Some aspects of the theories of interest (Walras, Böhm-Bawerk, Schumpeter) W. Hagemejer compiled and conducted an analysis of the interest theory created by Austrian and Swiss economists. The theory of capital and interest of Eugen von Böhm-Bawerk, known as the theory of circular production routes, indicated that although capital extends the production process over time, it nevertheless increases its effects in the form of greater production efficiency. According to E. von Böhm-Bawerk, it is not possible to explain the essence of profit from capital and the nature of interest without considering the time factor. Because people attribute a higher subjective value to current rather than future goods, a certain surplus, or agio, which is interest, appears. According to W. Hagemejer, because of its axiomatic character, the theory of capital of E. von Böhm-Bawerk is unprovable. In turn for Joseph A. Schumpeter, interest is the result of dynamic changes in the conditions of management. Inventions, which are new production combinations, make it possible to save labour input. Despite the fact that new production methods 
become widespread over time, the rate of return on capital remains at a higher level, even when the extraordinary profits of differential rent companies disappear. These quasi differential rents of J.A. Schumpeter considered it a condition for the existence of a rate of interest. This means that the differential rent is created thanks to technical innovation. J.A. Schumpeter, however, omitted the process of creating new capital by way of saving. This theory explains only changes in the interest rate in the short term. This gap is filled - according to the author of the article Some aspects of the theory of interest - with the forgotten theory of Leon Walras, for whom the rate of profit is the resultant of the states of equilibrium changing over time. This theory explains the changes in the long-term return on capital. Capitalization and the increase in new physical capital reduce the price of capital services and lead to a shift in the equilibrium point. The creation of new capital is the result of the aspiration of individuals to ensure stable income in the future (Hagemejer, 1935b, pp. 19-38).

A short biographical sketch devoted to Mieczysław Bochenek was also an expression of interest in the development of economic thought. W. Hagemejer gave the basic facts about Mieczysław Bochenek's life and his main achievements. W. Hagemejer (1936a, pp. 170-171) acknowledged two treatises as the basic works of M. Bochenek, in which he addressed the problem of the role of the Austrian State in relation to the railway undertaking and the Austrian tax system, with particular emphasis on land tax. In turn, he considered the theory of credit and the treasury to be the main areas of his interest.

Under the entry word Oszczędność (Saving), the W. Hagemejer (1939, pp. 167-169) analysed this category from various points of view and made reference to the most important doctrines. For the individual, that is a microeconomic business entity, saving consists in the abandoning of current consumption in the interest of future consumption. On the other hand, in the social holding, savings are allocated either to consumption or to investments. According to the predominant theories, the balance between savings and investments is maintained by the changing interest rate. There are also theories that indicate that some entities make decisions about the level of savings and other entities about the level of investment. The problem of savings became the subject of scientific considerations only for representatives of the classical school, mainly by D. Ricardo, J.B. Say, and T.R. Malthus. Later, the greatest contributors to the development of this theory were E. von Böhm-Bawerk, L. Walras, F.H. Knight, F.A. von Hayek, J.M. Keynes, and B.G. Ohlin.

\section{Application of mathematics in economics}

W. Hagemejer learnt the advantages of using the language of mathematics in the theory of economics as early as during his studies in Kraków. At that time he encountered A. Heydel, who, although he represented a psychological school, at the same time saw the benefits of the mathematizing of economics. He shared his fascination with his students and colleagues, and encouraged 
them to use the mathematical method. Believing in mathematical economics, W. Hagemejer used mathematics tools in most of his works. Both his doctoral thesis and other publications issued before and after World War II were mathematized. W. Hagemejer was also a convinced populariser of mathematical economics. This is evidenced by W. Hagemejer's work from 1966 entitled Wstęp informacyjny do programowania liniowego (Introduction of information to linear programming). It was one of the lectures prepared for the training conference on the application of mathematics in economics which took place in August 1966 in Jabłonna. The authors of the other lectures were: Prof. Dr Zdzisław Hellwig, Dr W. Przelaskowski, and Egon Vielrose. The aim of W. Hagemejer's study was to indicate to which fields of research and economic problems the optimization calculus is suited. Linear programming was created to compare the best solutions for specific economic tasks and to indicate an optimal solution when the available funds are limited. Small capitalist entrepreneurs did not need the theory of optimal decisions. Common sense and knowledge of the market were sufficient for them to make decisions. Sophisticated decision-making techniques and appropriate theories proved necessary along with the emergence of large organizations, characteristic of a mature capitalist economy. Programming techniques can be used wherever an improvement in decision-making is sought (Hagemejer, 1966b, pp. 5-7). The author of the study pointed out that 'the condition for the possibility of a theoretical examination of decisions from the point of view of optimality, and then the application of the programming technique to find the optimal decision is the possibility of quantifying the concept of optimum. In the theory of programming this requirement of quantification means that we must have a specific purpose function and the achievement of the maximum or minimum of this function means an optimal set of decisions regarding the arguments of this function' (Hagemejer, 1966b, p. 7). In what follows in his lecture he explained the problem of graphical interpretation of linear programming solutions, the Simplex method, the algebraic scheme of linear programming problems, the dual task, the transport task, and the inter-sectoral flows (Hagemejer, 1966b, pp. 10-48).

\section{Other issues}

The research topics presented above do not exhaust the full range of $\mathrm{W}$. Hagemejer's scientific interests. He undertook explanations of elementary concepts as well as complex problems. He interpreted the category of 'prosperity' in the Encyklopedia nauk politycznych (Encyclopaedia of political science). At the same time, he distinguished between individual and social prosperity. Social prosperity is determined by factors that affect the real income of society. The ways of increasing social prosperity comprise also the redistribution of income through an appropriate system of taxation, as well the elimination of inequalities in the distribution of income. The state can tax rich people and subsidize poorer people. Unfortunately, there is a danger of a decline in social income as 
a result of the weakening of the rate of capitalization caused by the policy of reducing income inequalities. However, according to W. Hagemejer (1936b, pp. 886-889), reduction of inequalities brings more benefits than costs.

W. Hagemejer (1938b, pp. 30-34) dealt with the problem of creating deposits by banks and the possibility of increasing capital in the economy in the article Some remarks on the creation of capital by the banking system. If cash reserves are growing, then investments may increase. When banks create more money, prices increase. In the conditions of full employment, forced savings must occur to create new capital. On the other hand, when the factors of production are not fully employed, the creation of money leads to an increase in the demand for capital goods and to a simultaneous increase in the production of consumer and investment goods.

In turn, the work entitled Zmiany materiatochtonności produkcji $i$ ich znaczenie dla gospodarki narodowej (Changes in raw material inputs in production and their importance for the national economy), written jointly with Bronisław Minc and Zbigniew Szulz, was a proposal to solve the shortage of raw materials and consumables. In their opinion, there were three ways to solve this problem, i.e. an increase in domestic production and import of materials, economical management of materials and improvement of the structure of industrial production, and a reduction in the share of materials placed at the forefront. The way to achieve this goal was to increase the refinement of production in the entire industry, which required many measures in the economic, technological, and organizational spheres. It was necessary to use known materials economically and to use new materials, new construction solutions, and new technologies (Minc et al., 1965, pp. 81-89).

In 1964, W. Hagemejer commented on the cyclical nature of Poland's economic development. In his opinion, the first cycle occurred in the years 19501958, while in the years 1959-1964 the beginning of the second cycle was observed. The technical side of investment processes was their source. The cyclical nature of development occurred independently of the planning calendar. Therefore, multiannual plans were not very effective. The investment rate was increased in an impulsive way to limits exceeding the possibilities of the economy, and these limits were assessed with excessive optimism. W. Hagemejer (1966a, pp. 169-170, 175-176) warned that in the future one should expect an echo of past cycles as reinvestment cycles, resulting from the concentration of large investments.

In the publication Proporcje tworzenia i podziatu dochodu narodowego (Proportions of production and distribution of national income) its author proposed an attempt to look critically at the planning model used then. The assessment of the planning model depends primarily on deviations in the implementation of planned tasks from the plan itself. However, it is a prerequisite that the plan falls within the area of possible solutions. The increase in material consumption in production was an unresolved problem. But the biggest weakness of the planning model were stocks. W. Hagemejer (1968, pp. 29-46) believed 
that as in the capitalist economy, stocks, in relation to investments, were low and showed a declining tendency. This tendency was a result of using modern programming methods in modern capitalist corporations. On the other hand, in the socialist economy, stocks grew with the increase of national income.

Finally, published in 1948, the academic coursebook entitled Pieniadz, kredyt, koniunktura i wymiana międzynarodowa (Money, credit, economic situation and international trade) included lectures given by W. Hagemejer (1948a, pp. 1 et seq.) at Nicolaus Copernicus University in Torun. They included a systematic course in economics, from the theory of consumer balance, through the banking system, to various business theories, and international exchange theory.

\section{Conclusion}

W. Hagemejer had the mind of an insightful analyst and the predispositions and skills of a mathematical economist and econometrist, as well as creative potential. Unfortunately, his promising scientific career was brutally interrupted, first by World War II, and later by unjustified arrest and imprisonment. The lack of professional stability was also a major obstacle. In total, he worked in seven scientific institutions over 33 years. Certainly, this has affected the number of publications left (30 items). Quantitatively, this output is not impressive, but it is interesting cognitively in several areas. His analyses of the condition of the Polish economy, filled with empirical data, are an excellent and faithful reflection of the then (difficult) reality. In the studies of demand elasticity he pointed to transport costs often overlooked in this type of studies. Market equilibrium, conditioning the sustainable development of the country's economy was the central category of his research. The issue of equilibrium was combined with extensive and methodical research into consumption, which included living costs, the income of the population (not only in Poland, but also in other countries), family budgets, and the structure and development trends of consumption of both urban and rural population. Thanks to his research on the purchasing power of money, he showed (together with W. Przelaskowski) that society was forced to save, and that inflation eroded this effort. By temporarily deferring demand, society lost the real value of their monetary resources. Despite the censorship control of the publication, he proved that in the centrally planned economy, in spite of government claims, inflation was present, and the burden of industrialization was borne by the whole of society at the expense of very low consumption. In addition, he pointed to the need to ensure the profitability of agricultural production and to reduce income inequalities between households. He also wrote a scientific biography of Mieczysław Bochenek - the author of the first post-doctoral (habilitacja) thesis in economics in Kraków. Convinced of the benefits of using mathematics in economics, in most of his works he used the language of mathematics and rich statistical material, and he also popularized mathematical economics. It is also worth emphasizing that he was the first professor of economics at the University of Torun 
and, together with his wife, began the Hagemejer family (three generations). Unfortunately, W. Hagemejer was forgotten by Polish economists, and war veterans, and suffered politically repression.

\section{References}

Fiejka, Z., Hagemejer, W., Przelaskowski, W., Rey, K., Rychlewski, E., \& Szulz, Z. (1959). Równowaga i nierównowaga rynkowa w Polsce w roku 1957. Studia Ekonomiczne, 2.

Górski, L., Schmidt, L., \& Hagemejer, W. (1937). Land reform and decapitalisation. Studia Ekonomiczne. Economic Studies, 4.

Hagemejer, W. (1935a). Elastyczność popytu na przewóz towarów. Studja Ekonomiczne. Economic Studies, 1.

Hagemejer, W. (1935b). Some aspects of the theories of interest (Walras, BöhmBawerk, Schumpeter). Studja Ekonomiczne. Economic Studies, 2.

Hagemejer, W. (1936a). Bochenek Mieczysław. In W. Konopczyński (Ed.), Polski Stownik Biograficzny, 2. Kraków: Polska Akademia Umiejętności.

Hagemejer, W. (1936b). Dobrobyt. In E.J. Reyman, \& W. Grabski (Ed.), Encyklopedja nauk politycznych: zagadnienia spoteczne, polityczne i gospodarcze, 1 . Warszawa: Wydawnictwo Instytutu Społecznego i Instytutu Wydawniczego „Bibljoteka Polska”.

Hagemejer, W. (1938a). Konsumcja. In E.J. Reyman, \& W. Grabski (Ed.), Encyklopedja nauk politycznych: zagadnienia spoteczne, polityczne i gospodarcze, 3. Warszawa: Wydawnictwo Instytutu Społecznego i Instytutu Wydawniczego „Bibljoteka Polska”.

Hagemejer, W. (1938b). Some remarks on the creation of capital by the banking system. Studia Ekonomiczne. Economic Studies, 5.

Hagemejer, W. (1939). Oszczędność. In E.J. Reyman, \& W. Grabski (Ed.), Encyklopedja nauk politycznych: zagadnienia spoteczne, polityczne i gospodarcze, 4. Warszawa: Wydawnictwo Instytutu Społecznego i Instytutu Wydawniczego „Bibljoteka Polska”.

Hagemejer, W. (1947a). General survey. Biuletyn Instytutu Gospodarstwa Narodowego, 5.

Hagemejer, W. (1947b). Przegląd ogólny. Biuletyn Instytutu Gospodarstwa Narodowego, 5 .

Hagemejer, W. (1947c). Przegląd ogólny. Biuletyn Instytutu Gospodarstwa Narodowego, 6 .

Hagemejer, W. (1948a). Pieniądz, kredyt, koniunktura i wymiana międzynarodowa: wedtug wyktadów prof. dr Wt. Hagemejera. Toruń: Koło Prawników Studentów U.M.K.

Hagemejer, W. (1948b). Przegląd ogólny. Biuletyn Instytutu Gospodarstwa Narodowego, 7.

Hagemejer, W. (1957). Sytuacja gospodarcza w I półroczu 1957 r. Z Prac Zakładu Nauk Ekonomicznych PAN, 3. 
Hagemejer, W. (1958). Sytuacja gospodarcza w 1957 r. Z Prac Zaktadu Nauk Ekonomicznych PAN, 4.

Hagemejer, W. (1963a). Równowaga rynkowa, równowaga agregatowa, równowaga bilansowa. Studia Ekonomiczne, 8.

Hagemejer, W. (1963b). Uwagi o cenach i kosztach w rolnictwie. In W. Hagemejer, K. Sokołowski, \& S. Felbur (Eds.). W sprawie „Ogólnej opłacalności produkcji rolnej”, Studia Ekonomiczne, 9.

Hagemejer, W. (1966a). Speech In Sprawozdanie z konferencji naukowej dla uczczenia XX-lecia Polski Ludowej, przeprowadzonej w dniu 14 grudnia 1964 r. przez Komitet Nauk Ekonomicznych PAN, Polskie Towarzystwo Ekonomiczne, Szkołę Główną Planowania i Statystyki, Wyższą Szkołę Nauk Społecznych, Wydział Ekonomiczny UW i Zakład Nauk Ekonomicznych PAN. Studia Ekonomiczne, 15.

Hagemejer, W. (1966b). Wstęp informacyjny do programowania liniowego. In W. Hagemejer, Z. Hellwig, W. Przelaskowski, \& E. Vielrose, Zagadnienia matematyki stosowanej w ekonomii. Wrocław-Warszawa-Kraków: Zakład Narodowy im. Ossolińskich, Wydawnictwo PAN.

Hagemejer, W. (1968). Proporcje tworzenia i podziału dochodu narodowego: uwagi o modelu planowania. In M. Falkowski (Ed.), Kierunki usprawnień metod planowania i zarządzania gospodarką narodową. Warszawa: PWN.

Hagemejer, W. (n.d.). Personal files of Professor Włodzimierz Hagemejer (file K-9/266). Archives of Nicolaus Copernicus University in Torun, Poland.

Hagemejer, W., \& Przelaskowski, W. (1963). Handel wewnętrzny i spożycie w latach 1955-1960. Studia Ekonomiczne, 8.

Hagemejer, W., \& Przelaskowski, W. (1965a). Rezerwy pieniężne ludności, dochody i równowaga. Studia Ekonomiczne, 14.

Hagemejer, W., \& Przelaskowski, W. (1965b). Tendencje rozwojowe spożycia w okresie lat 1949-1963. Roczniki Instytutu Handlu Wewnętrznego, 3(35).

Hagemejer, W., \& Przelaskowski, W. (1966a). Handel wewnętrzny i spożycie w latach 1960-1963. Studia Ekonomiczne, 15.

Hagemejer, W., \& Przelaskowski, W. (1966b). Metodologia międzynarodowych porównań dochodów ludności. Studia Ekonomiczne, 16.

Hagemejer, W., \& Przelaskowski, W. (1967). Vètrešna targovija i potreblenieto v Polšě prez perioda 1960-1964. Ikonomičeska Mysl, 1.

Hagemejer, W., \& Przelaskowski, W. (1968). Problemy sity nabywczej pieniądza. Warszawa: PWN.

Hagemejer, W., Przelaskowski, W. (1958). Siła nabywcza złotego polskiego w stosunku do rubla i funta szterlinga: próba szacunku. Z Prac Zakładu Nauk Ekonomicznych PAN, 5.

Kowalik, T. (2006). Spory o ustrój spoteczno-gospodarczy w Polsce: lata 1944-1948. Warszawa: Key Text.

Minc, B., Hagemejer, W., Szulz, Z. (1965). Zmiany materiałochłonności produkcji i ich znaczenie dla gospodarki narodowej. Studia Ekonomiczne, 14. 
Polskie Towarzystwo Ekonomiczne. (2005). Biuletyn Polskiego Towarzystwa Ekonomicznego, 3.

Żukowski, P.M. (2017). Wydziat Prawa Uniwersytetu Jagiellońskiego w Krakowie w latach 1918-1939. Kraków: Księgarnia Akademicka.

\section{Acknowledgements}

Author contributions: the author has given an approval to the final version of the article.

Funding: this research was funded by the author's own resources. 
